\title{
Effect of Sugar Content on Acetaldehyde Yield in Cigarette Smoke*
}

\author{
by \\ Xavier Cahours ${ }^{1}$, Thomas Verron ${ }^{1}$, and Steve Purkis ${ }^{2}$ \\ ${ }^{1}$ SEITA, Imperial Tobacco Group 48, rue Danton, 45404 Fleury-les-Aubrais, France \\ ${ }^{2}$ Imperial Tobacco Limited, PO Box 525, Winterstoke Road, Bristol BS99 1LQ, UK
}

\section{SUMMARY}

The relationship between cigarette blend sugar and acetaldehyde formed in its smoke is a matter of current regulatory interest. This paper provides a re-analysis of data from 83 European commercial cigarettes studied in the 1970 s and more modern data on sugar levels and acetaldehyde yields from a series of 97 European commercial cigarettes containing both inherent sugar and in other cases inherent and added sugar. It also provides data from 65 experimental cigarette products made from single curing grades of tobacco, having a wide range of inherent sugar levels but no added sugar.

This study has shown that there is no relationship between acetaldehyde yields and blend sugar content even if a multivariate analysis is carried out taking into account Nicotine Free Dry Particulate Matter (NFDPM) as a co-factor. Such analyses should take into consideration each of the known contributory factors in order to avoid misleading conclusions.

No distinction was found between the mainstream acetaldehyde yields from dark air-cured, flue-cured or US blended style cigarettes irrespective of their sugar content after taking account of differences in NFDPM yields. Similarly, no distinction was found between mainstream acetaldehyde yields of cigarettes made from single grades of either flue-cured, sun-cured or air-cured tobaccos with no sugar added.

This work supports the conclusion that structural material in the tobacco plant is the main source of acetaldehyde in mainstream smoke after combustion during cigarette smoking. [Beitr. Tabakforsch. Int. 25 (2012) 381-395]

\section{ZUSAMMENFASSUNG}

Das Verhältnis zwischen dem Zuckergehalt einer Zigarettentabakmischung und dem im Rauch gebildeten
Acetaldehyd ist von aktuellem regulatorischem Interesse. Diese Veröffentlichung zeigt eine Reanalyse des Zuckergehaltes und Acetaldehydwerten von 83 europäischen kommerziellen Zigaretten, die in den 1970er Jahren untersucht wurden, sowie aktuelleren Daten einer Serie von 97 europäischen kommerziellen Zigaretten, die zum Teil nur tabakeigenen Zucker und in anderen Fällen tabakeigenen und zugesetzten Zucker enthalten. Zudem präsentiert diese Veröffentlichung Daten von 65 experimentellen Zigaretten, die aus einzelnen Tabaksorten bestehen und unterschiedliche Mengen an tabakeigenem Zucker, aber keinen zugesetzten Zucker, enthalten.

Diese Untersuchung zeigt, dass der Acetaldehydgehalt im Rauch nicht mit dem Zuckergehalt der Tabakmischung in Beziehung steht, auch wenn eine mulitvariate Analyse durchgeführt wird und der Wert des nikotinfreien Trockenkondensats (NFDPM - Nicotine Free Dry Particulate Matter) als Kofaktor berücksichtigt wird. Um irreführende Schlussfolgerungen bei solchen Analysen zu vermeiden, sollte jeder der bekannten, beeinflussenden Faktoren mit berücksichtigt werden.

Nachdem die unterschiedlichen NFDPM-Werte einbezogen wurden, konnte zwischen dem Acetaldehydgehalt im Hauptstromrauch der unterschiedlichen Zigaretten (Zigaretten aus dunklem luftgetrockneten Tabak, Zigaretten aus ofengetrocknetem Tabak oder US-AmericanBlend-Zigaretten) kein Unterschied festgestellt werden, gleichgültig wie viel Zucker sie enthalten. Genauso wird kein Unterschied zwischen dem Acetaldehydgehalt im Hauptstromrauch von Zigaretten festgestellt, die jeweils aus einzelnen Tabaksorten bestehen und denen kein Zucker zugesetzt wurde.

Diese Arbeit unterstützt die Schlussfolgerung, dass die Hauptquelle für den Acetaldehydgehalt im Hauptstromrauch, der bei der Verbrennung des Tabaks während des Rauchens einer Zigarette entsteht, das strukturelle Material der Tabakpflanze selber ist. [Beitr. Tabakforsch. Int. 25 (2012) 381-395]

*Received: $1^{\text {st }}$ December 2011 - accepted: $12^{\text {th }}$ May 2012 


\section{RESUME}

La relation entre le sucre contenu dans les mélanges de tabac de cigarette et l'acétaldéhyde formé dans sa fumée a fait l'objet d'un intérêt constant de la part des autorités de régulation au cours des dernières décennies. Le présent document propose une nouvelle analyse des données de 83 marques de cigarettes européennes commercialisées, étudiées dans les années 1970, ainsi que de données plus récentes relatives aux concentrations en sucre et aux teneurs en acétaldéhyde pour un groupe de 97 marques de cigarettes européennes commercialisées contenant soit du sucre naturel soit du sucre naturel et du sucre ajouté. Cette étude fournit également des données concernant 65 produits de cigarette expérimentaux fabriqués à partir d'une seule qualité de séchage de tabac, contenant un large éventail de concentrations de sucre naturel, mais pas de sucre ajouté. Cette étude a montré qu'il n'y a pas de relation entre les teneurs en acétaldéhyde et les concentrations en sucre contenu dans le mélange de tabac, même si une analyse multivariée a été menée en tenant compte de la matière particulaire anhydre et exempte de nicotine (MPAEN) en tant que co-facteur. De telles analyses devraient prendre en considération chacun des facteurs connus intervenant afin de prévenir toute conclusion erronée.

Aucune distinction n'a été détectée entre les teneurs en acétaldéhyde dans la fumée principale de cigarette des tabacs bruns séchés à l'air naturel, des tabacs séchés à l'air chaud ou des cigarettes de type " American Blend ", peu importe leur concentration en sucre respective, après avoir pris en considération les différences au niveau de teneur en MPAEN. De la même manière, aucune distinction n'a pu être établie entre les teneurs en acétaldéhyde présentes dans la fumée principale de cigarette pour des cigarettes fabriquées à partir d'une seule qualité de tabac, soit séché à l'air chaud, soit séché au soleil, soit séché à l'air naturel, sans sucre ajouté.

Le présent travail appuie les conclusions selon lesquelles de la matière structurelle dans la plante de tabac est la principale source de l'acétaldéhyde présent dans la fumée principale de cigarette après la combustion durant le fumage de la cigarette. [Beitr. Tabakforsch. Int. 25 (2012) 381-395]

\section{INTRODUCTION}

Acetaldehyde is the most abundant component in the vapour phase of cigarette mainstream smoke after oxygen, nitrogen, water, carbon monoxide and carbon dioxide. In isolation, it has been classified as an animal carcinogen (1) and may be cytotoxic or genotoxic (2).

A review of the scientific literature concluded that natural tobacco polysaccharides, such as cellulose, when combusted during smoking, are likely to be the main precursors of acetaldehyde in cigarette mainstream smoke (3).

Soluble sugars such as fructose, glucose and sucrose are natural components of tobacco (4). Sugars in tobacco are formed via enzymatic hydrolysis of starch during the period after priming and the early stages of the curing process. The sugar content of tobacco types is highly variable, but primarily depends on the method of curing. Soluble sugars are frequently added to the tobacco blend in the form of casings, typically to air-cured leaf components that have extremely low sugar contents due to losses occurring during curing. US blended style cigarettes contain blends of air-, sun- and flue-cured tobaccos, with an overall sugar content, inherent and added, that is generally similar or lower than flue-cured Virginia style cigarettes and can be evidenced by the data provided in this study. Both reducing (e.g., fructose and glucose) and non-reducing (e.g., sucrose) sugars contribute to tobacco smoke flavour and act as humectants in many tobacco products.

The relationship between cigarette blend sugar and acetaldehyde formed in its smoke is a matter of current regulatory interest (5-7). In a report requested by the European Commission, the Scientific Committee on Emerging and Newly Identified Health Risks (SCENIHR) concluded that acetaldehyde, given intravenously, is addictive and enhances the addictiveness of nicotine in experimental animals. They reported a hypothesis, that there is a possible action of combustion products of sugars, such as acetaldehyde and similar compounds, which enhances the addictiveness of nicotine probably by their interaction with other smoke components to form compounds such as harmans that inhibit monoamine oxidase. However, this was unsubstantiated with scientific evidence. Contrary to this hypothesis, they also reported that heavy smokers absorb only minor amounts of acetaldehyde in the blood and harman compounds are formed at very low levels in smoke.

Acetaldehyde and other aliphatic aldehydes, such as formaldehyde and acrolein, can be generated by the pyrolysis of sugar (5). Other workers (8) have reported that pyrolysis of simple sugars favours the formation of furan compounds whereas pyrolysis of cellulose favours the formation of anhydrosugars and small molecules such as acetaldehyde. Similar observations were made from data generated in our own laboratories in unpublished work. However, products formed during pyrolysis experiments either on sugars alone or even when mixed with tobacco depend on the pyrolysis conditions and generally pyrolysis does not well predict ingredient fate during combustion in a cigarette during smoking (9).

In a recent paper, the addition of sucrose at $1.5 \%$ to $4.8 \%$ to the tobacco blend of test cigarettes did not lead to any significant increases in acetaldehyde yields in smoke (7). This supports the large body of tobacco industry literature (10-14) that has demonstrated that cigarettes with or without added sugar, or indeed other additives, produce similar acetaldehyde concentrations in relation to Nicotine Free Dry Particulate Matter (NFDPM) during smoking. It may be said that, if anything, additives tend to reduce such smoke yields by decreasing the relative amount of tobacco in the blend by replacement with the additive (15). These findings concur with our own data both published (13) and unpublished at commercial sugar usage levels.

In 1975, PhillPOTTS et al. (16) reported no correlation between the total aldehyde yields in cigarette mainstream smoke and tobacco blend sugar contents of 83 commercial European brands. Some authors (17) have recently re-interpreted the PHILlpotTs data differently. They suggested applying a multivariate analysis taking into consideration NFDPM yields that gave a significant sugar-aldehyde relationship, with an $\mathrm{R}^{2}$ correlation equal to 
Table 1. Data on cigarettes made from individual tobacco grades.

\begin{tabular}{|c|c|c|c|c|c|}
\hline Curing type ${ }^{a}$ & Country of origin & $\begin{array}{c}\text { Total sugar }^{\mathrm{b}} \\
\%\end{array}$ & $\begin{array}{c}\text { Acetaldehyde yield } \\
(\mu \mathrm{g} / \mathrm{cig})\end{array}$ & $\begin{array}{c}\text { NFDPM yield }^{\mathrm{C}} \\
(\mathrm{mg} / \mathrm{cig})\end{array}$ & $\begin{array}{c}\text { Acetaldehyde / NFDPM ratio } \\
(x \text { 1000) }\end{array}$ \\
\hline Sun & China & 4.4 & 538.9 & 10.7 & 50.3 \\
\hline Sun & China & 12.9 & 658.3 & 12.5 & 52.7 \\
\hline Sun & Greece & 3.6 & 592.8 & 13.1 & 45.2 \\
\hline Sun & Greece & 6.9 & 771.0 & 18.5 & 41.7 \\
\hline Sun & Greece & 12.0 & 697.5 & 18.4 & 38.0 \\
\hline Sun & Lebanon & 7.6 & 634.7 & 19.6 & 32.4 \\
\hline Sun & Lebanon & 12.3 & 683.0 & 18.4 & 37.1 \\
\hline Sun & Macedonia & 8.9 & 689.8 & 19.0 & 36.3 \\
\hline Sun & Macedonia & 9.6 & 676.2 & 18.0 & 37.7 \\
\hline Sun & Syria & 5.8 & 591.2 & 19.5 & 30.3 \\
\hline Sun & Turkey & 15.0 & 693.8 & 17.0 & 40.7 \\
\hline Sun & Turkey & 4.0 & 588.5 & 16.3 & 36.1 \\
\hline Sun & Turkey & 9.0 & 547.9 & 14.1 & 38.8 \\
\hline Sun & Turkey & 15.3 & 672.6 & 18.8 & 35.8 \\
\hline Sun & Turkey & 12.9 & 622.5 & 18.1 & 34.4 \\
\hline Sun & Bulgaria & 12.2 & 458.7 & 20.5 & 22.3 \\
\hline Air & Argentina & 0.0 & 574.2 & 11.1 & 51.8 \\
\hline Air & Brazil & 0.0 & 567.6 & 12.5 & 45.6 \\
\hline Air & China & 0.0 & 658.4 & 10.6 & 62.3 \\
\hline Air & China & 0.0 & 612.1 & 12.4 & 49.4 \\
\hline Air & China & 0.0 & 662.5 & 14.9 & 44.6 \\
\hline Air & China & 0.1 & 477.3 & 7.1 & 67.6 \\
\hline Air & China & 0.0 & 507.8 & 12.8 & 39.8 \\
\hline Air & France & 0.0 & 567.0 & 9.3 & 61.0 \\
\hline Air & France & 0.3 & 630.4 & 7.4 & 85.5 \\
\hline Air & France & 0.0 & 493.8 & 10.9 & 45.3 \\
\hline Air & France & 0.0 & 601.0 & 12.1 & 49.6 \\
\hline Air & France & 0.0 & 506.9 & 7.1 & 71.3 \\
\hline Air & India & 0.0 & 574.9 & 11.4 & 50.4 \\
\hline Air & India & 0.0 & 483.9 & 12.5 & 38.7 \\
\hline Air & India & 0.0 & 577.4 & 15.2 & 38.1 \\
\hline Air & Italy & 0.2 & 432.3 & 9.9 & 43.6 \\
\hline Air & Italy & 0.0 & 606.0 & 10.5 & 57.9 \\
\hline Air & Korea & 0.0 & 532.0 & 12.2 & 43.5 \\
\hline Air & Malawi & 0.0 & 633.0 & 11.4 & 55.5 \\
\hline Air & Malawi & 0.0 & 630.4 & 10.4 & 60.9 \\
\hline Air & Malawi & 0.0 & 578.4 & 15.3 & 37.8 \\
\hline Air & Malawi & 0.0 & 589.4 & 10.4 & 56.9 \\
\hline Air & Thailand & 0.0 & 501.0 & 12.6 & 39.9 \\
\hline Air & Thailand & 0.0 & 621.7 & 17.2 & 36.3 \\
\hline Air & Thailand & 0.0 & 470.8 & 17.4 & 27.0 \\
\hline Air & Thailand & 0.0 & 537.8 & 7.8 & 69.4 \\
\hline Air & USA & 0.0 & 668.8 & 12.6 & 53.1 \\
\hline Air & USA & 0.0 & 644.6 & 9.7 & 66.4 \\
\hline Air & Zimbabwe & 0.0 & 670.9 & 9.7 & 69.4 \\
\hline Flue & Argentina & 8.8 & 596.9 & 12.8 & 46.5 \\
\hline Flue & Brazil & 1.3 & 609.3 & 16.2 & 37.6 \\
\hline Flue & Brazil & 7.0 & 671.2 & 17.2 & 38.9 \\
\hline Flue & Brazil & 2.3 & 548.4 & 8.1 & 67.5 \\
\hline Flue & China & 14.3 & 593.0 & 18.2 & 32.6 \\
\hline Flue & China & 7.7 & 613.6 & 19.7 & 31.2 \\
\hline Flue & China & 17.1 & 665.5 & 18.5 & 36.0 \\
\hline Flue & Spain & 9.1 & 578.7 & 21.2 & 27.4 \\
\hline Flue & China & 10.3 & 551.2 & 9.2 & 60.0 \\
\hline Flue & France & 23.7 & 609.6 & 12.8 & 47.5 \\
\hline Flue & France & 23.1 & 683.9 & 13.6 & 50.4 \\
\hline Flue & France & 9.8 & 497.8 & 8.9 & 55.8 \\
\hline
\end{tabular}


Table 1. (cont.).

\begin{tabular}{l|c|c|c|c|c}
\hline Curing type $^{\mathrm{a}}$ & Country of origin & $\begin{array}{c}\text { Total sugar }^{\mathrm{b}} \\
\%\end{array}$ & $\begin{array}{c}\text { Acetaldehyde yield } \\
(\mu \mathrm{g} / \mathrm{cig})\end{array}$ & $\begin{array}{c}\text { NFDPM yield }{ }^{\mathrm{c}} \\
(\mathrm{mg} / \mathrm{cig})\end{array}$ & $\begin{array}{c}\text { Acetaldehyde / NFDPM ratio } \\
(\mathrm{x} 1000)\end{array}$ \\
\hline Flue & India & 2.5 & 619.9 & 10.6 & 58.7 \\
Flue & India & 13.1 & 710.5 & 13.7 & 51.8 \\
Flue & India & 2.0 & 586.1 & 22.3 & 26.2 \\
Flue & India & 7.1 & 706.0 & 20.6 & 34.3 \\
Flue & India & 1.3 & 659.1 & 11.6 & 56.7 \\
Flue & Kenya & 9.9 & 635.2 & 12.1 & 52.6 \\
Flue & Tanzania & 6.1 & 618.5 & 11.9 & 52.1 \\
Flue & Zimbabwe & 12.0 & 547.6 & 12.2 & 45.0 \\
\hline
\end{tabular}

a Sun = sun-cured tobaccos; air = air-cured tobaccos; flue = flue-cured tobaccos

b Total sugar $=($ fructose + glucose + sucrose $)$

c $\quad$ NFDPM $=$ Nicotine Free Dry Particulate Matter

$34 \%$, and they concluded that normalising for NFDPM may obscure a sugar-aldehyde relationship. This current paper describes some further analysis to examine the claims made by these authors.

This paper also provides more up-to-date data on sugar levels and acetaldehyde yields from a series of commercial products and from cigarettes made from single curing grades of tobacco, having a wide range of inherent sugar levels but no added sugar. Similar multivariate analyses were also undertaken on data from these cigarettes to investigate relationships between these blend sugars and smoke acetaldehyde yields.

\section{EXPERIMENTAL}

\section{Analyses carried out by PHILLPOTTS et al. in 1975}

Blend sugars levels and total aldehyde yields in cigarette smoke were measured by colorimetric methods. PHILlPOTTS et al. briefly described how total sugars were estimated by hydrolysis of tobacco with mineral acid at $95^{\circ} \mathrm{C}$ to give the reducing sugars. These were dialysed then oxidised with alkaline potassium ferricyanide. The colour loss was then measured. Total volatile aldehydes were determined by a procedure based on the Tobacco Research Council (18) standard method after smoking according to the puffing parameters later set out in the ISO 3308 standard (19). Whole smoke was collected at $-80{ }^{\circ} \mathrm{C}$ and extracted with ethanol.

Aldehydes were reacted with 3-methyl-2-benzothiazolone hydrazone hydrochloride and ferric chloride to give a blue colour. Reaction and colour measurements for both blend sugars and total volatile aldehydes smoke were performed in a Technicon AutoAnalyser.

\section{Preparation of experimental cigarettes}

Experimental cigarettes were made from single tobacco grades, having a wide range of inherent sugar levels but having no added sugar. The experimental cigarettes were constructed using product design characteristics similar to brands of commercial cigarettes.

Each of the cigarettes were cellulose acetate filtered cigarettes (cigarette length: $84 \mathrm{~mm}$ and filter length: $21 \mathrm{~mm}$ ) and with a filter ventilation level at $15 \%$. The cigarettes were made to the same pressure drop (50 mm WG (water gauge)). To keep this constant, target tobacco weights were adjusted according to the tobacco density.

\section{Commercially available cigarettes}

Five data sets were obtained in 5 different years (2001, 2005, 2006, 2008, and 2010) on 97 commercial brands from the EU market: 12 from Eastern Europe (Poland, Hungary, Ukraine, and Russia); 32 from France; 14 from Germany; 8 from Spain, and 31 from UK. These products reflected the different design features used in products made by the Imperial Tobacco Group (ITG). These products also include some major brands made by other manufacturers. It can be noted that the 2001 products were identical to those studied in the UK smoke constituent study (20).

\section{Analyses}

In this work, glucose, fructose, and sucrose were extracted from cigarette filler with water and determined using a continuous flow procedure. This analysis was divided into three steps.

(1) The amount of glucose was determined. Glucose was phosphorylated by adenosine triphosphate (ATP) in a reaction catalysed by hexokinase. Glucose-6-phosphate (G6P) was then oxidised to 6-phosphogluconate in the presence of nicotinamide adenine dinucleotide (NAD) with catalysis by glucose-6-phosphate dehydrogenase (G6PDH). During this oxidation, an equimolar amount of NAD was reduced to NADH. The consequent increase in absorbance at $340 \mathrm{~nm}$ was directly proportional to the glucose concentration.

(2) Fructose was also phosphorylated by ATP and converted to glucose 6-phosphate by phosphoglucose isomerase (PGI). This step determined the sum of glucose and fructose concentrations.

(3) Sucrose was hydrolysed using $\beta$-fructosidase. Glucose and fructose resulting from this degradation were analysed as described above. This last step determined the sum of glucose, fructose and sucrose concentrations. By subtraction of results obtained in the different steps, the 
Table 2. Data on commercial cigarette brands.

\begin{tabular}{|c|c|c|c|c|c|c|}
\hline Country of sale ${ }^{a}$ & Brand Name & Year & $\begin{array}{l}\text { Blend } \\
\text { type }\end{array}$ & $\begin{array}{c}\text { Total Sugar }^{c} \\
\% \\
\end{array}$ & $\begin{array}{l}\text { Acetaldehyde } \\
\text { Yield } \\
\end{array}$ & $\begin{array}{l}\text { NFDPM } \\
\text { Yield }^{f}\end{array}$ \\
\hline $\mathrm{F}$ & Benson \& Hedges ${ }^{d}$ & 2006 & US & 5.3 & 413.0 & 8.3 \\
\hline UK & Benson \& Hedges $\mathrm{KS}^{\mathrm{d}}$ & 2001 & UK & 8.5 & 720.0 & 9.9 \\
\hline UK & Berkeley Superkings ${ }^{d}$ & 2001 & UK & 7.7 & 705.0 & 9.9 \\
\hline SP & BN Clásico & 2010 & Dark & 0.3 & 420.0 & 6.5 \\
\hline UK & Camel Ultra Lights ${ }^{d e}$ & 2001 & US & 8.0 & 167.0 & 2.7 \\
\hline UK & Consul Menthol $^{d}$ & 2001 & UK & 8.7 & 514.0 & 7.3 \\
\hline G & Davidoff Magnum & 2005 & UK & 12.4 & 513.0 & 11.1 \\
\hline SP & Ducados Azul & 2010 & Dark & 0.3 & 480.3 & 9.2 \\
\hline $\mathrm{F}$ & Dunhill $^{d}$ & 2006 & UK & 7.5 & 517.0 & 9.6 \\
\hline $\mathrm{F}$ & Fine 120 Menthol & 2010 & UK & 6.2 & 547.5 & 9.2 \\
\hline $\mathrm{F}$ & Fine Bleu Super Slims & 2010 & UK & 6.8 & 358.1 & 7.5 \\
\hline EE & Fine King Size Filter & 2006 & US & 10.7 & 867.0 & 12.2 \\
\hline $\mathrm{F}$ & Fortuna Rouge & 2006 & US & 9.2 & 548.0 & 9.9 \\
\hline SP & Fortuna Azul & 2010 & US & 6.4 & 458.3 & 7.5 \\
\hline G & Fortuna Red & 2010 & US & 5.9 & 594.6 & 9.7 \\
\hline SP & Fortuna Rojo & 2010 & US & 6.9 & 588.6 & 10.0 \\
\hline SP & Fortuna Silver & 2010 & US & 6.0 & 306.5 & 4.1 \\
\hline$P$ & Fox & 2010 & US & 3.0 & 587.9 & 10.9 \\
\hline $\mathrm{F}$ & Gauloise Blonde Bleu & 2006 & US & 9.1 & 590.0 & 10.4 \\
\hline $\mathrm{F}$ & Gauloise Blonde Blanc Bleu & 2006 & US & 9.5 & 292.0 & 4.7 \\
\hline $\mathrm{F}$ & Gauloise Blonde Rouge & 2006 & US & 8.8 & 412.0 & 6.8 \\
\hline $\mathrm{F}$ & Gauloise Blonde Jaune & 2006 & US & 9.5 & 251.0 & 2.4 \\
\hline $\mathrm{F}$ & Gauloise Blonde Jaune International & 2010 & US & 7.1 & 273.4 & 3.7 \\
\hline $\mathrm{F}$ & Gauloise Blonde Bleu International & 2010 & US & 5.9 & 716.1 & 10.2 \\
\hline $\mathrm{F}$ & Gauloise & 2010 & Dark & 0.3 & 591.4 & 10.7 \\
\hline $\mathrm{F}$ & Gauloise Brunes & 2006 & Dark & 0.9 & 585.0 & 9.9 \\
\hline $\mathrm{F}$ & Gauloise Selection Red & 2010 & US & 6.5 & 431.4 & 6.2 \\
\hline UK & Gitanes & 2001 & Dark & 1.6 & 687.0 & 11.9 \\
\hline $\mathrm{F}$ & Gitanes Blondes Blanc Bleu & 2010 & US & 6.2 & 493.7 & 7.3 \\
\hline $\mathrm{F}$ & Gitanes Filter & 2010 & Dark & 0.3 & 641.5 & 8.5 \\
\hline $\mathrm{F}$ & Gitanes Maïs & 2010 & Dark & 0.3 & 664.3 & 8.6 \\
\hline $\mathrm{F}$ & JPS & 2006 & US & 9.0 & 535.0 & 9.5 \\
\hline UK & L\&B Gold & 2008 & UK & 10.1 & 339.2 & 5.0 \\
\hline UK & L\&B KS & 2008 & UK & 11.6 & 598.8 & 9.9 \\
\hline UK & L\&B KS & 2001 & UK & 8.8 & 758.0 & 12.0 \\
\hline UK & L\&B Lights $\mathrm{KS}^{\mathrm{e}}$ & 2001 & UK & 7.9 & 463.0 & 5.9 \\
\hline UK & L\&B Ultra Lights ${ }^{\mathrm{e}}$ & 2001 & UK & 8.6 & 108.0 & 1.8 \\
\hline UK & L\&B White & 2008 & UK & 10.0 & 89.8 & 1.9 \\
\hline $\mathrm{F}$ & Lucky Strike Red $^{d}$ & 2006 & US & 6.0 & 486.0 & 10.0 \\
\hline $\mathrm{F}$ & Lucky Strike Silver ${ }^{d}$ & 2006 & UK & 6.0 & 366.0 & 6.8 \\
\hline $\mathrm{F}$ & Marlboro $^{d}$ & 2006 & US & 9.4 & 527.0 & 9.5 \\
\hline UK & Marlboro KS ${ }^{d}$ & 2001 & US & 9.5 & 716.0 & 12.4 \\
\hline UK & Marlboro Light ${ }^{\mathrm{d} e}$ & 2001 & US & 9.7 & 402.0 & 5.7 \\
\hline G & Marlboro Gold $^{d}$ & 2006 & US & 9.5 & 466.0 & 7.8 \\
\hline G & Marlboro Blend $29^{d}$ & 2006 & US & 8.8 & 425.0 & 7.1 \\
\hline $\mathrm{F}$ & Marlboro Menthol White ${ }^{d}$ & 2006 & US & 9.4 & 452.0 & 7.4 \\
\hline UK & Mayfair Lights ${ }^{d} \mathrm{e}$ & 2001 & UK & 7.5 & 520.0 & 7.4 \\
\hline UK & Mayfair Menthol $^{d}$ & 2001 & UK & 6.5 & 349.0 & 8.4 \\
\hline$F$ & MonteCristo & 2006 & US & 7.4 & 590.0 & 10.1 \\
\hline SP & Nobel Triple Filter & 2010 & US & 5.3 & 340.1 & 5.9 \\
\hline $\mathrm{F}$ & Peter Stuyvesant Bleu & 2006 & US & 7.4 & 232.0 & 4.2 \\
\hline $\mathrm{F}$ & Peter Stuyvesant Silver & 2006 & US & 5.3 & 59.0 & 1.3 \\
\hline $\mathrm{F}$ & Peter Stuyvesant Menthol & 2006 & US & 9.4 & 529.0 & 9.7 \\
\hline $\mathrm{F}$ & Philip Morris Crème ${ }^{d}$ & 2006 & US & 9.5 & 449.0 & 7.3 \\
\hline $\mathrm{F}$ & Philip Morris One ${ }^{d}$ & 2006 & US & 8.9 & 75.0 & 1.3 \\
\hline SP & Popularne & 2010 & US & 4.6 & 521.0 & 11.2 \\
\hline EE & Prima Lux Red & 2005 & US & 7.1 & 510.1 & 10.8 \\
\hline EE & Prima Lux Red & 2008 & US & 7.3 & 511.6 & 10.8 \\
\hline
\end{tabular}


Table 2. (cont.).

\begin{tabular}{|c|c|c|c|c|c|c|}
\hline Country of Sale ${ }^{a}$ & Brand Name & Year & $\begin{array}{l}\text { Blend } \\
\text { type }\end{array}$ & $\begin{array}{c}\text { Total Sugar } \\
\%\end{array}$ & $\begin{array}{c}\text { Acetaldehyde } \\
\text { Yield }\end{array}$ & $\begin{array}{l}\text { NFDPM } \\
\text { Yield }^{f}\end{array}$ \\
\hline EE & Prima Lux Blue & 2008 & US & 7.2 & 333.6 & 7.2 \\
\hline EE & Prima Lux Menthol & 2008 & US & 7.3 & 388.3 & 7.2 \\
\hline EE & Prima Lux Zolota & 2008 & US & 7.6 & 283.4 & 3.9 \\
\hline EE & Prima Oval & 2008 & US & 5.7 & 563.8 & 13 \\
\hline EE & Red \& White & 2006 & US & 8.0 & 544.0 & 9.8 \\
\hline G & R1 Blue & 2008 & US & 7.5 & 42.0 & 1.0 \\
\hline G & R1 Light Flavour & 2005 & US & 7.8 & 90.9 & 2.0 \\
\hline G & R1 Red & 2008 & US & 7.5 & 87.1 & 2.0 \\
\hline G & R1 Red & 2010 & US & 5.7 & 123.8 & 1.8 \\
\hline UK & Red Band Lights ${ }^{e}$ & 2001 & UK & 9.2 & 351.0 & 6.1 \\
\hline UK & Regal Filter & 2001 & UK & 8.2 & 631.0 & 11.6 \\
\hline UK & Regal KS & 2001 & UK & 9.7 & 872.0 & 12.6 \\
\hline G & Roth Haendle & 2005 & Dark & 2.5 & 326.1 & 10.5 \\
\hline G & Roth Haendle & 2008 & Dark & 2.6 & 325.8 & 10.6 \\
\hline UK & Roth Red & 2001 & UK & 8.9 & 661.0 & 10.1 \\
\hline UK & Roth Red 120s & 2001 & UK & 9.8 & 567.0 & 9.3 \\
\hline$F$ & Royale Anise & 2010 & US & 11.5 & 284.3 & 4.8 \\
\hline$F$ & Royale Menthol & 2006 & US & 6.3 & 526.0 & 10.2 \\
\hline$F$ & Royale Menthol & 2010 & US & 7.0 & 581.5 & 9.6 \\
\hline$F$ & Royale Silver & 2006 & US & 4.3 & 144.0 & 1.2 \\
\hline UK & Senior Service & 2001 & UK & 8.8 & 523.0 & 12.5 \\
\hline UK & Silk Cut Extra Mild ${ }^{d e}$ & 2001 & UK & 10.2 & 183.0 & 2.6 \\
\hline UK & Silk Cut KS ${ }^{d}$ & 2001 & UK & 10.1 & 367.0 & 4.8 \\
\hline UK & Silk Cut Ultra Light de & 2001 & UK & 9.4 & 73.0 & 1.3 \\
\hline UK & Superkings & 2001 & UK & 8.6 & 778.0 & 11.5 \\
\hline UK & Superkings Lights ${ }^{\mathrm{e}}$ & 2001 & UK & 7.6 & 505.0 & 8.3 \\
\hline UK & Superkings Ultra Lights ${ }^{\mathrm{e}}$ & 2001 & UK & 8.1 & 268.0 & 2.6 \\
\hline UK & Superkings & 2005 & UK & 11.2 & 453.3 & 9.3 \\
\hline UK & Superkings Blue & 2008 & UK & 9.3 & 392.6 & 8.8 \\
\hline UK & Superkings White & 2005 & UK & 7.0 & 209.9 & 3.8 \\
\hline EE & Tiger & 2006 & US & 5.6 & 506.0 & 9.7 \\
\hline UK & Vogue $^{d}$ & 2001 & US & 7.7 & 346.0 & 7.6 \\
\hline G & West Ice & 2005 & US & 8.9 & 298.5 & 6.7 \\
\hline EE & West Stream Tec Silver & 2008 & US & 7.8 & 382.2 & 6.3 \\
\hline G & West Red & 2010 & US & 5.58 & 524.8 & 8.7 \\
\hline G & West Red & 2008 & US & 9.8 & 526.4 & 10.2 \\
\hline G & West Red 100 & 2008 & US & 8.8 & 435.2 & 10.3 \\
\hline G & West Silver & 2008 & US & 8.9 & 336.9 & 6.8 \\
\hline EE & West Silver Multifilter & 2008 & US & 10.6 & 218.9 & 6.9 \\
\hline
\end{tabular}

a Countries of sale: $E E$ = Eastern Europe; F = France; G = Germany; SP = Spain; UK = United Kingdom

b Blend style: Dark = contains high proportion of dark air-cured tobacco; UK = contains mainly flue-cured tobacco; US = contains a blend of sun-cured, air-cured and flue-cured tobaccos

c Total sugar $=$ fructose + glucose + sucrose

d Other manufacturer brands (non ITG)

e These cigarettes were manufactured and tested before EU legislation banned the descriptors such as "light", "mild" and "ultra-light" 2003 (28).

f $\quad$ NFDPM = Nicotine Free Dry Particulate Matter

concentrations of glucose, fructose, and sucrose in analysed tobacco were obtained (21). Two replicate determinations were made.

Total sugar was estimated as the sum of sucrose, glucose, and fructose. Other sugars are present in tobacco but only at very low levels (22).

\section{NFDPM measurement}

In each of the studies the NFDPM yields were conditioned and measured using the appropriate ISO standards (23-26) according to the puffing parameters set out in the ISO 3308 (19). Two replicates of 20 cigarettes were smoked for each cigarette type.

\section{Acetaldehyde measurement}

Acetaldehyde analysis was carried out on commercial cigarettes containing the blends analysed for sugar and on cigarettes made from individual tobacco grades, collecting smoke using the ISO smoking regime (19) according to an in-house method involving derivatisation to the 


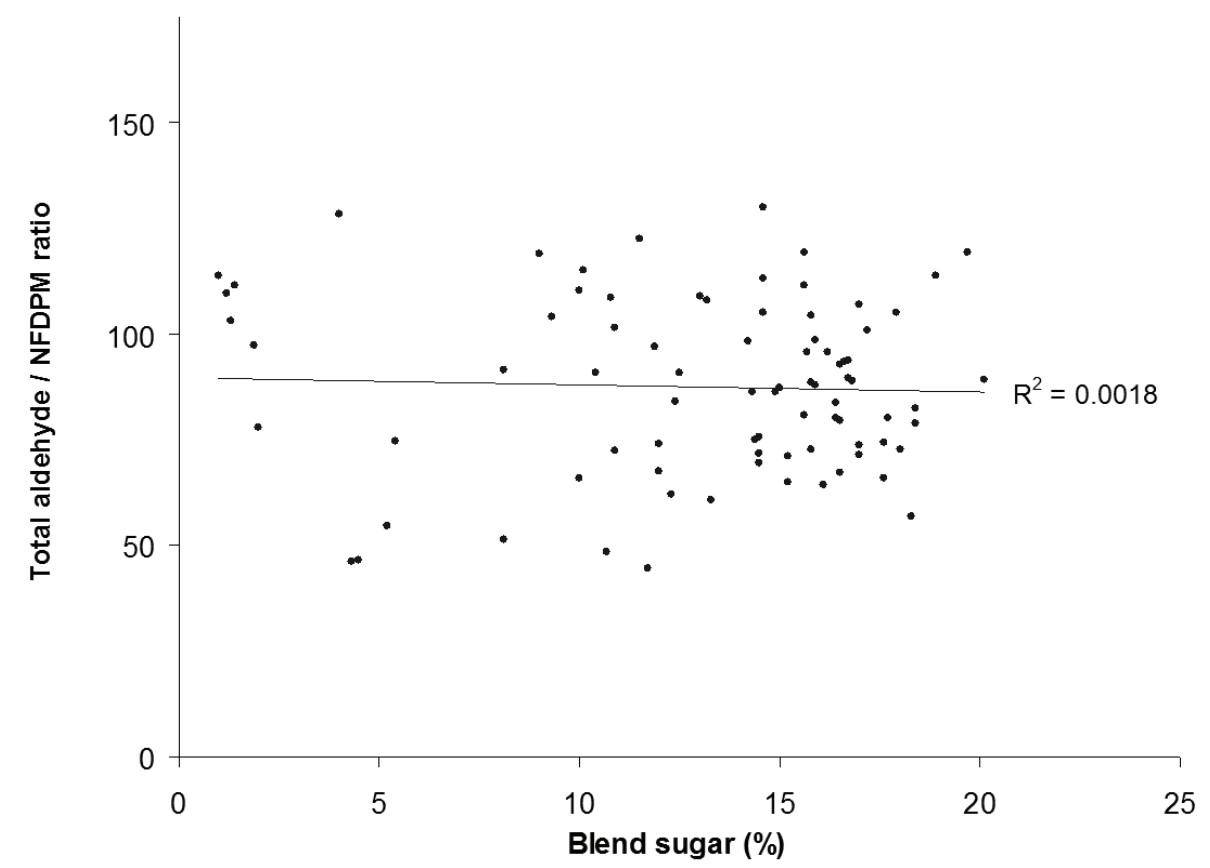

Figure 1. Relationship between total aldehydes / NFDPM ratio in cigarette smoke and blend sugar content from all brands studied by PHILLPOTTS et al. (16). NFDPM = Nicotine Free Dry Particulate Matter

dinitrophenylhydrazone, separation by high performance liquid chromatography and ultra violet detection, similar to a method described in the literature (27). Two replicates of 2 cigarettes were smoked for each cigarette type.

\section{RESULTS}

Analysis of commercial European brands in 1975

PhiLlpotTs et al. (16) reported total volatile aldehyde yields and blend sugar contents measured by colorimetry. Their data was used for the statistical analyses described in this paper.

\section{Analysis of tobacco grades}

Sixteen sun-cured grades, 29 air-cured grades and 20 flue-cured grades were studied with no added sugar. Table 1 lists the countries of origin and curing types studied along with their sugar content. Air-cured grades ranged in sugar content from $0.0-0.3 \%$ sun-cured grades from $3.6-15.3 \%$, and flue-cured grades from $1.3-23.7 \%$. The NFDPM and acetaldehyde yields and acetaldehyde / NFDPM ratios of cigarettes made from the studied grades are also listed in Table 1.

In spite of the similar cigarette constructions, tobaccos had different densities and weights and this resulted in the different NFDPM yields from the finished experimental cigarettes.

\section{Analysis of current commercial products}

The sugar content of the commercial products depends on curing types used in the cigarette blends and levels are variable as shown in Table 2. Dark air-cured blends contained typically much less than $2 \%$ total sugar. Flue-cured blends had no added sugar and contained 6-13\% inherent sugar. US blended style tobacco blends had a mixture of inherent sugar and sugar added to the air-cured tobacco component. Even so, the total sugar content of US blended style products still tended to be lower (3-12\%) than flue-cured products. The NFDPM and acetaldehyde yields are also listed in Table 2.

\section{DISCUSSION}

In 1975, PHILLPOTTS et al. (16) reported no correlation $\left(\mathrm{R}^{2}=\right.$ 0.0018 ) between the ratio of total aldehyde to NFDPM in smoke and the tobacco blend sugar content from 83 commercial European brands as shown in Figure 1. These colorimetric measurement methods were unspecific but it was estimated from in-house experiments that about $85 \%$ of the measured aldehydes was due to acetaldehyde. In 1982, a published study (29), involving 25 different experimental cigarettes, had shown a correlation between, in this case, acetaldehyde in mainstream smoke and total reducing sugars in the tobacco blend. The relationship is given in Figure 2. However, the NFDPM yields of the studied cigarette ranged from 4-26 mg/cig and it was therefore necessary to normalise the mainstream smoke acetaldehyde yields by dividing by the NFDPM yields of each cigarette to make 


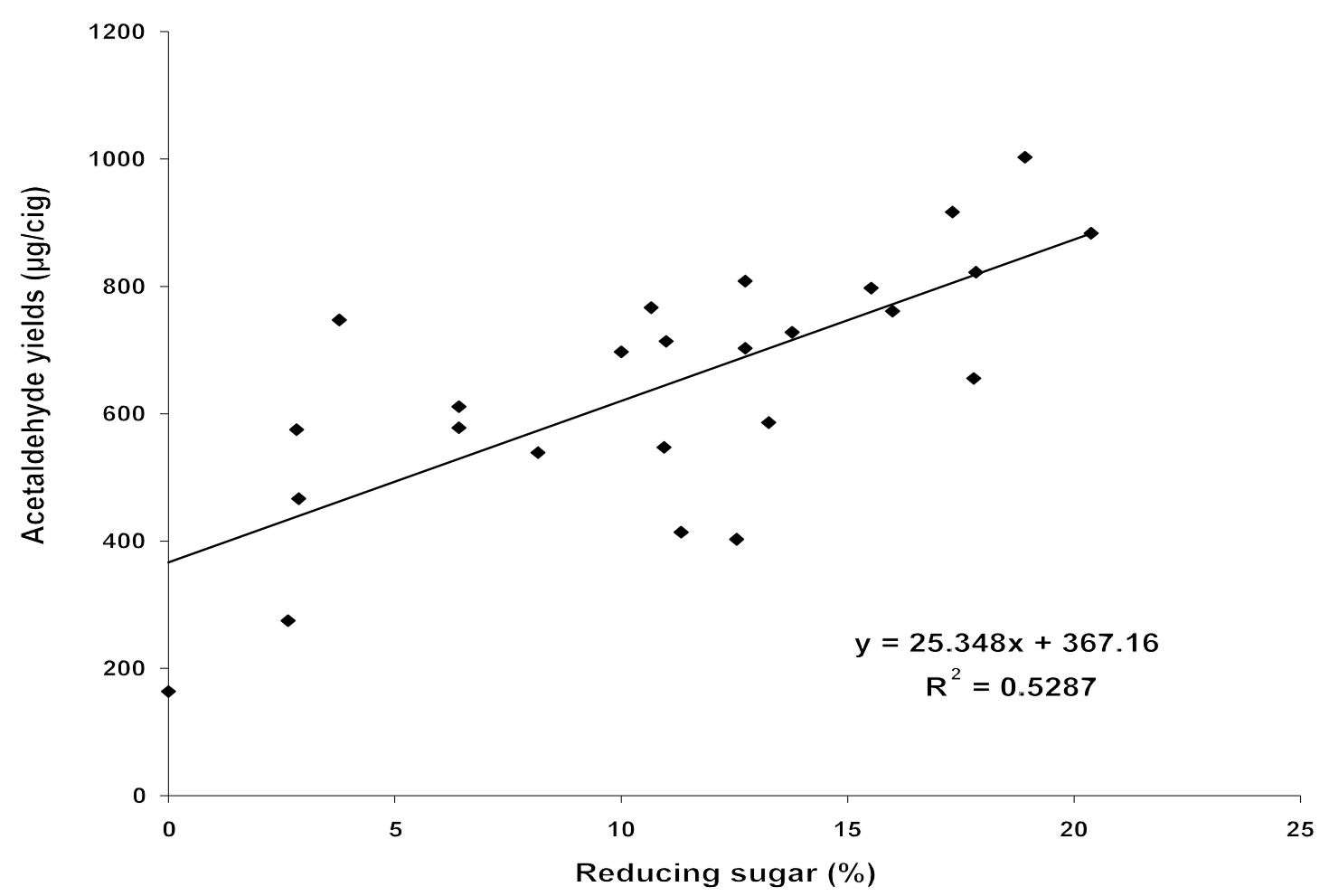

Figure 2. Relationship between acetaldehyde in cigarette smoke and blend reducing sugar content from data by ZILKEY et al. (29).

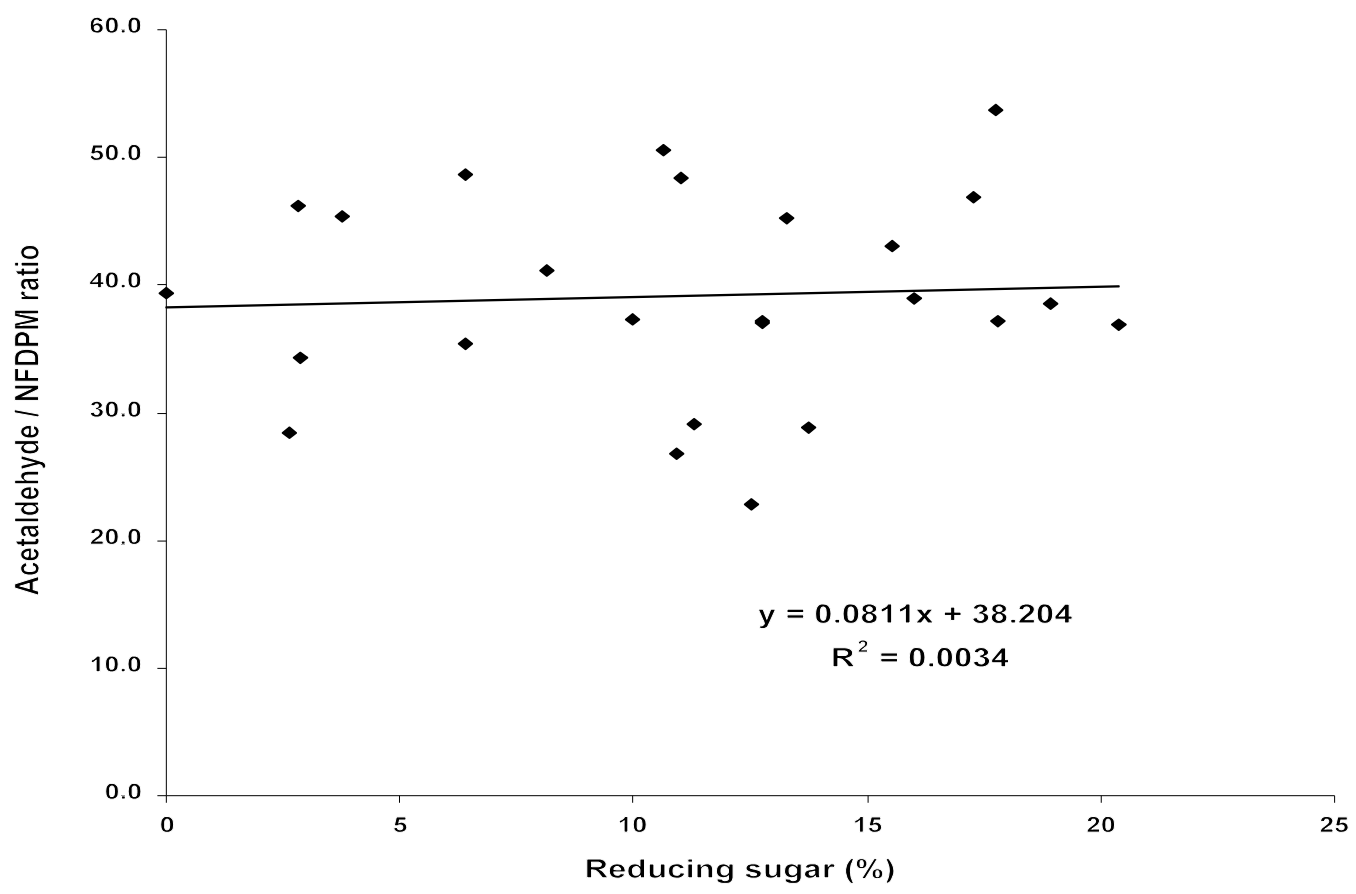

Figure 3. Relationship between acetaldehyde / NFDPM ratio and blend reducing sugar content from data by ZILKEY et al. (29). NFDPM $=$ Nicotine Free Dry Particulate Matter 
Table 3. Correlation of reducing sugars in the blend with smoke acetaldehyde yields and with smoke acetaldehyde / NFDPM ratios from SEEMAN et al. (30).

\begin{tabular}{l|c|c|c}
\hline \multirow{2}{*}{ Year } & \multirow{2}{*}{$\begin{array}{c}\text { Number of } \\
\text { brands }\end{array}$} & \multicolumn{2}{l}{ Correlation $\left(\mathrm{R}^{2}\right)$ of reducing sugars with: } \\
\cline { 3 - 4 } & 135 & 0.0899 & $\begin{array}{c}\text { Acetaldehyde / } \\
\text { NFDPM }\end{array}$ \\
\hline 1985 & 142 & 0.0715 & 0.0000 \\
1986 & 185 & 0.0872 & 0.0000 \\
1987 & 176 & 0.2349 & 0.0004 \\
1988 & 4 & $N^{a}$ & 0.0074 \\
1989 & 116 & 0.1633 & ND \\
1990 & 264 & 0.1387 & 0.0206 \\
1991 & 420 & 0.0847 & 0.0004 \\
1992 & 102 & 0.0436 & 0.0541 \\
1993 & & & 0.0209 \\
\hline
\end{tabular}

a ND = not determined due to small sample size

b NFDPM = Nicotine Free Dry Particulate Matter

comparisons. After normalisation, this study also showed no significant correlation $\left(\mathrm{R}^{2}=0.0034\right)$ between the ratio of mainstream smoke acetaldehyde / NFDPM and total reducing sugar content as shown in Figure 3.

In 2003, a benchmark study (30) on a large number of US cigarettes (gathered over the time period 1985-1993) had shown that the concentration of reducing sugars in the tobacco was not correlated to the acetaldehyde yield or its concentration in NFDPM in mainstream smoke as shown in Table 3. These authors concluded that mainstream smoke acetaldehyde was mainly derived from polysaccharides, such as cellulose.

In 2009, O'CONNOR and HURLEY (17) re-investigated and interpreted the data of PHILLPOTTS et al. (16) differently. The authors suggested applying a multivariate analysis to provide the relationship between total smoke aldehydes and blend sugars taking into account the NFDPM yields. They reported that if NFDPM is first forced into the model it accounts for $23 \%$ of variance in aldehyde yield. If sugar content is added to the model then it is a significant predictor and accounts for an additional $11 \%$ of variance in aldehydes. In the current paper, these figures have been derived again in the way described below with some further perspective put on the analyses and conclusions from the data.

A simple linear regression, as used by PHILlPOTTS, named a bivariate model, involves two variables, one is a dependent variable, in this case total volatile aldehydes, and one is an independent variable, in this case NFDPM.

$$
\text { Total volatile aldehydes }=\alpha+\beta \times \text { NFDPM }
$$

In their re-analysis, these authors (17) decided to use only

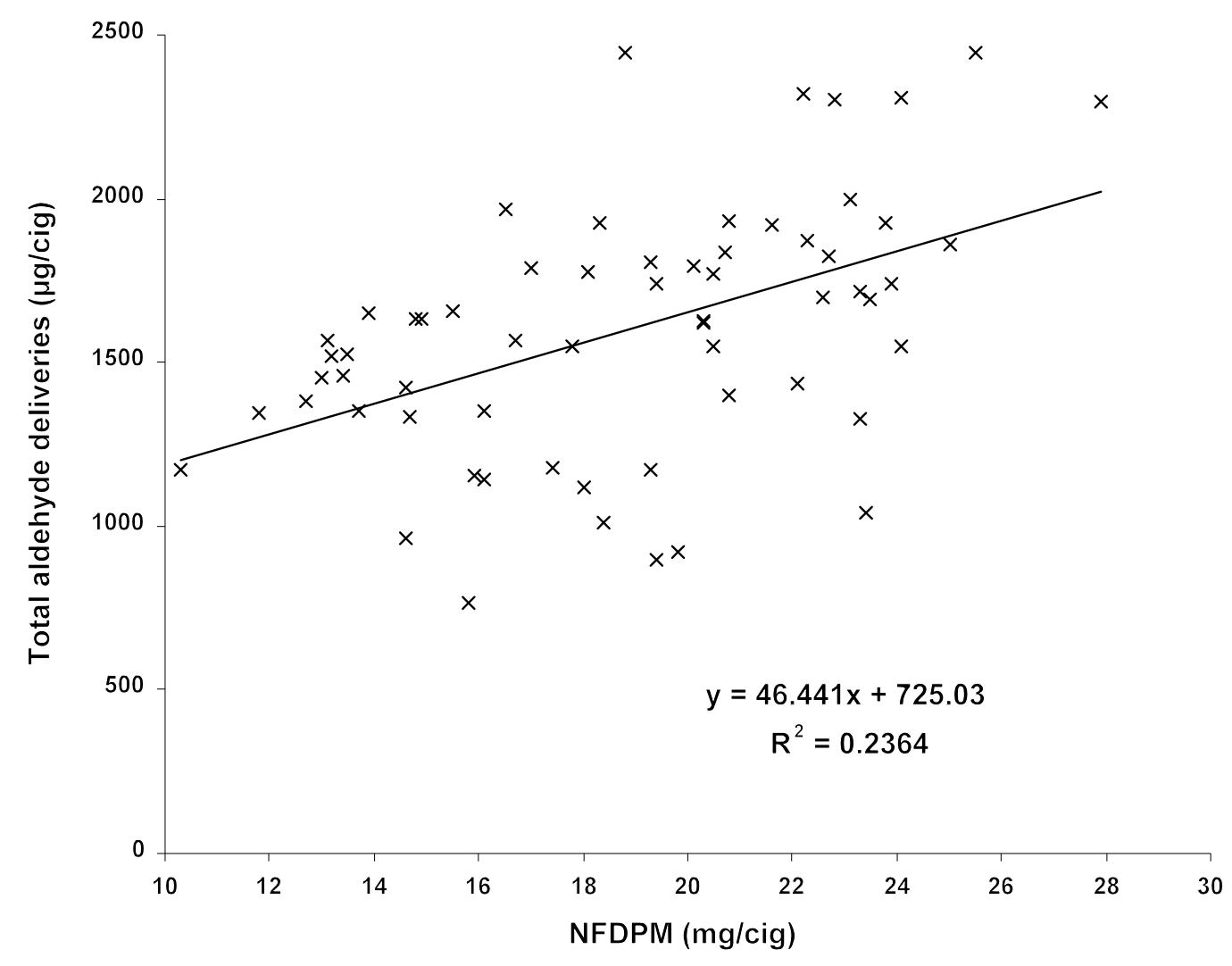

Figure 4. Relationship between total aldehyde yields in cigarette smoke and NFDPM yields from filter cigarettes studied by PHILLPOTTS et al. (16). NFDPM = Nicotine Free Dry Particulate Matter 


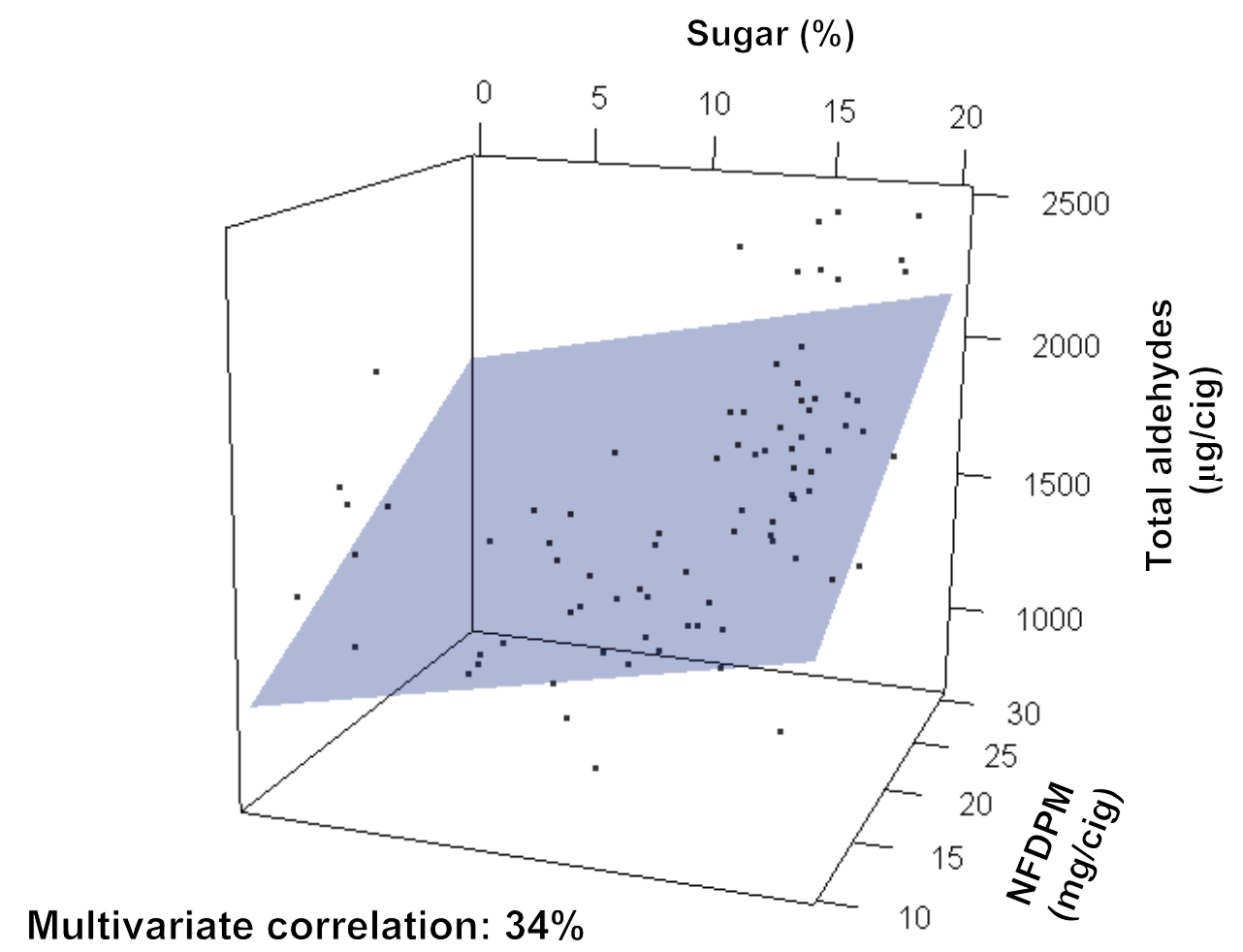

Figure 5. Multivariate analysis of total smoke aldehyde yields, NFDPM smoke yields and blend sugar content from filter cigarettes studied by PHILLPOTTS et al. (16). NFDPM = Nicotine Free Dry Particulate Matter

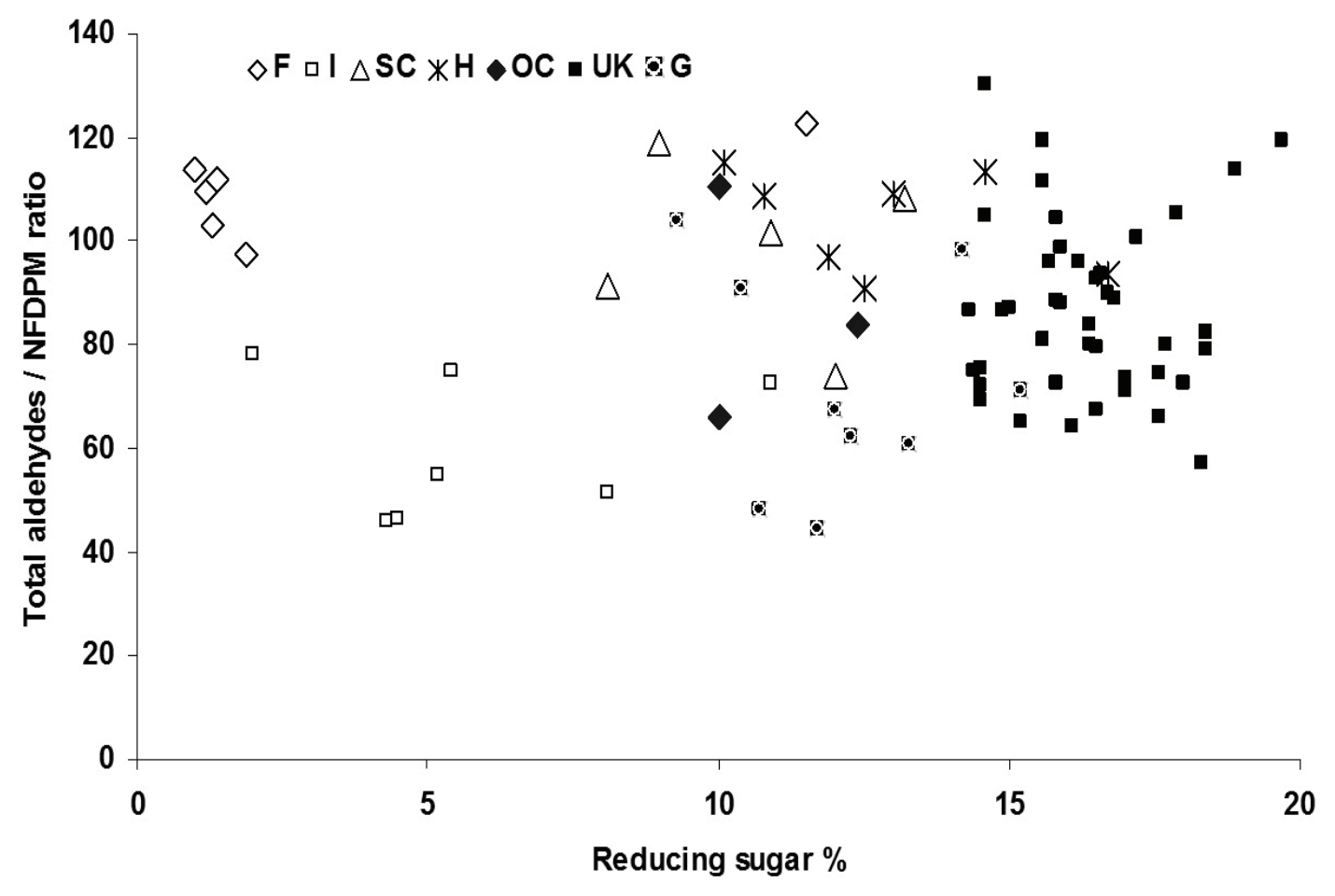

Figure 6. Relationship between total aldehyde / NFDPM ratios and blend sugar contents using data from PHILLPOTTS et al. (16) separated by different countries of sale.

$\mathrm{F}=$ France; I = Italy; Sc = Scandinavia (Denmark, Norway); H = Holland; OC = Other countries (Belgium, Luxembourg, Switzerland); UK = United Kingdom; $\mathrm{G}=$ Germany;

NFDPM = Nicotine Free Dry Particulate Matter 
Table 4. Multivariate analysis of the effects of various factors on total aldehyde yields using data from PHILLPOTTS et al. (16).

\begin{tabular}{lcc|c|r|c|c}
\hline Factors & Sum of squares & Degrees of freedom & Mean squares & F ratio & P value & Significance \\
\hline Filter or plain & 124805 & 1 & 124805 & 1.86 & 0.1772 & NO \\
Country of sale $_{\text {NFDPM }}{ }^{\text {a }}$ & $2.86515 \mathrm{E} 6$ & 6 & 477525 & 7.11 & 0.0000 & YES \\
Sugar $_{\text {Residue }}^{876612}$ & 5697.82 & 1 & 876612 & 13.05 & 0.0006 & YES \\
Total & $4.83815 \mathrm{E} 6$ & 1 & 5697.82 & 0.08 & 0.7717 & NO \\
\hline
\end{tabular}

a $\quad$ NFDPM $=$ Nicotine Free Dry Particulate Matter

the data from filter cigarettes and derived an $\mathrm{R}^{2}$ correlation of $0.24 \%$ from the bivariate model as reproduced in Figure 4 . In other words, NFDPM accounts for $24 \%$ of the variance in total aldehyde yields. However, to be complete, a qualitative factor with both modalities (filter or plain cigarettes) should have been added to the model.

A multiple regression is a multivariable model, with one dependent variable and multiple independent variables.

Total volatile aldehydes $=\alpha+\beta_{1} \times$ NFDPM $+\beta_{2} \times$ Sugar

A multivariate analysis was carried out in the same way described by O'CONNOR and HURLEY (17) and is depicted in Figure 5, NFDPM and sugar take account of $34 \%$ of the variance in aldehyde yields leading to their conclusion that sugar accounts for an additional $11 \%$ in variance in aldehydes.

However, multivariate analysis should be based on the statistical principle of observation and analysis of more than one statistical variable at a time. For acetaldehyde yields, the technique should take account of all variables that might affect yields in order to avoid any misleading conclusions. PHILLPOTTS et al. (16) had pointed out that Italian brands had low sugar and low aldehyde yield whilst French brands had even lower sugar but higher aldehyde yield. They concluded that the low aldehyde yield measured in Italian brands could be due to other properties rather than their low sugar content. At that time, the style of products (based on tobacco curing types used in blends) smoked in those countries was substantially different to those, for example, smoked in the UK. Tobacco curing types in the blends in certain countries, used by other manufacturers, were not known by PHILlPOTTs et al. .

If the "country" factor is added to the analysis then a lack of correlation with different countries of sale is found as depicted in Figure 6.

Therefore, the multivariate analysis used by O'CONNOR and HURLEY (17) was incomplete and could have generated misleading conclusions. In order to further investigate this statistical approach, a multivariate analysis based on the General Linear Model (GLM) was carried out. This GLM study has been applied using each of the factors described in the paper by PHILLPOTTS et al. (16); that is, sugar, NFDPM, filter or plain cigarette type and country of sale.

Acetaldehyde $=\alpha+\beta_{1} \times$ Filter or Plain $+\beta_{2} \times$ Country $+\beta_{3}$ $\times \mathrm{NFDPM}+\beta_{4} \times$ Sugar

Table 4 shows that the country and NFDPM yield have a significant effect on total volatile aldehyde yield whereas the cigarette design with filter or without (plain) and the level of blend sugar do not affect the yield.

As the country effect is significant and the global effect of sugar is not significant, the model has been refined by nesting the sugar factor in the country factor in order to assess whether there is a significant effect of sugar for each country.

Acetaldehyde $=\alpha+\beta_{1} \times$ Country $+\beta_{2} \times$ NFDPM $+\beta_{3} \times$ Sugar (Country)

Table 5. Multivariate analysis of the effects of various factors on total aldehyde yields with the sugar factor nested in the country factor using data from PHILLPOTTS et al. (16).

\begin{tabular}{|c|c|c|c|c|}
\hline \multirow{2}{*}{ Sugar factor nested in (Country) } & \multirow{2}{*}{ Model coefficient ( $\beta 3$ ) } & \multicolumn{2}{|c|}{ Confidence interval at $95 \%$} & \multirow{2}{*}{ Significance } \\
\hline & & Lower limit & Upper limit & \\
\hline France & 4 & -25.0 & 34.7 & $\mathrm{NS}^{\mathrm{a}}$ \\
\hline Holland & 3.2 & -94.9 & 101.2 & $\mathrm{NS}^{\mathrm{a}}$ \\
\hline Italy & 6.9 & -69.5 & 83.4 & $\mathrm{NS}^{\mathrm{a}}$ \\
\hline Scandinavia $^{\mathrm{b}}$ & -0.4 & -129.5 & 128.8 & $\mathrm{NS}^{\mathrm{a}}$ \\
\hline United Kingdom & -14.8 & -77.3 & 47.6 & $\mathrm{NS}^{\mathrm{a}}$ \\
\hline Germany & 2.9 & -99.0 & 104.9 & $\mathrm{NS}^{\mathrm{a}}$ \\
\hline Other countries ${ }^{c}$ & -7.7 & -65.4 & 50.0 & $\mathrm{NS}^{\mathrm{a}}$ \\
\hline
\end{tabular}

a $\quad$ NS = non significant

b Scandanavia = Norway and Denmark

c Other countries = Belgium, Luxemburg and Switzerland 


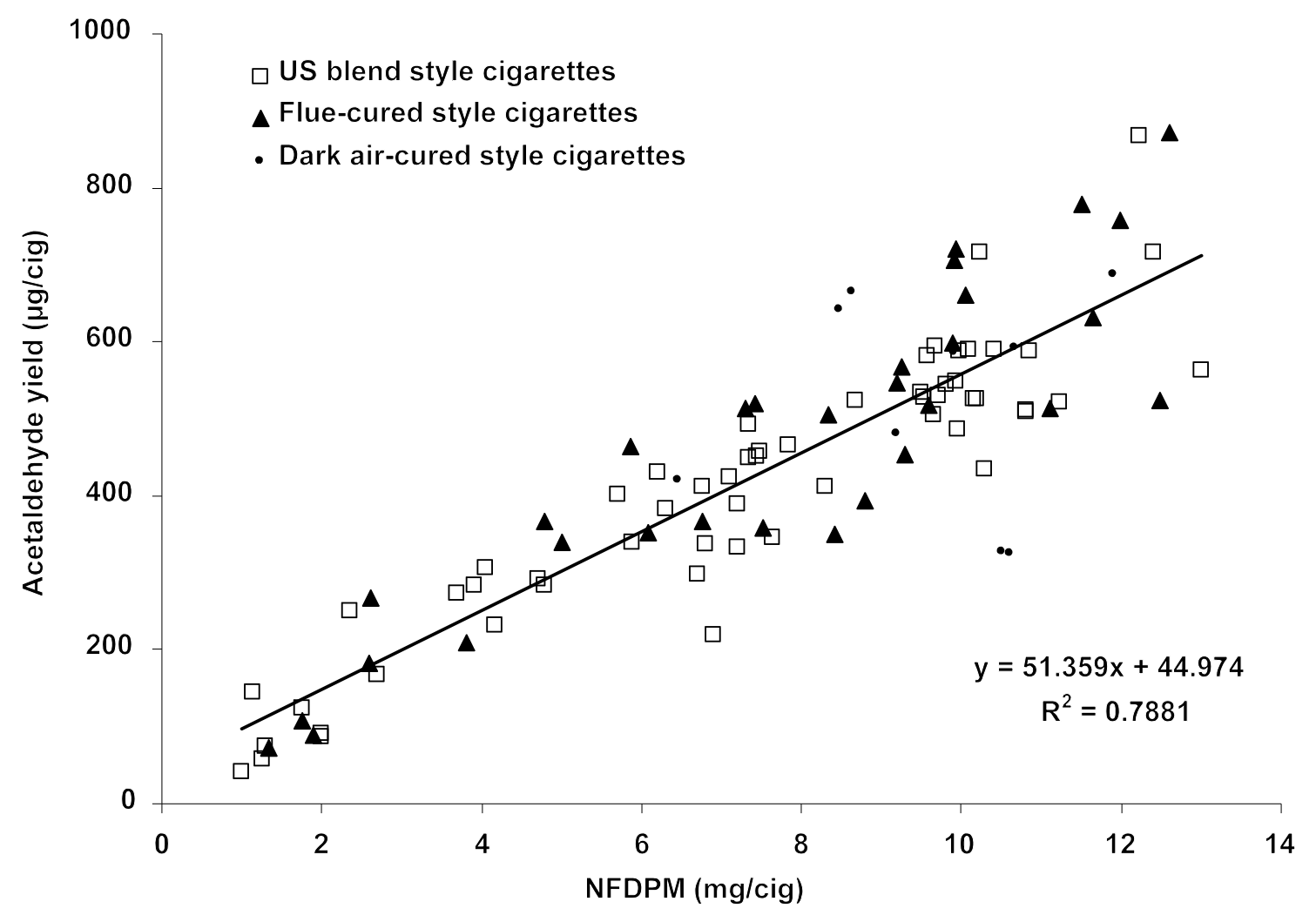

Figure 7. Relationship between acetaldehyde and NFDPM yields in current commercial cigarettes. NFDPM = Nicotine Free Dry Particulate Matter

As the design factor (filter or plain) was not significant, it was not included in the analysis.

The GLM analysis estimates the effect (model coefficients: $\beta_{3}$ ) of blend sugar for each country. The effect of sugar for a country is significant when the estimated value is different from zero. On the other hand, an estimated value is not different from zero when the effect is non-significant. Table 5 shows the model coefficients and their confidence intervals for each country estimated by the GLM analysis. Each of the confidence intervals, the difference between the upper and lower limits, includes the zero value indicating that the model coefficients are not significant. Therefore, there is no effect of blend sugar content on aldehyde yields whatever the country.

\section{Analysis of tobacco grades and commercial brands}

The PhillpotTs data was obtained for products on sale 35 years ago. The next part of this study provides an additional data analysis on modern commercially available products. Five data sets were obtained by our laboratory. A total of 97 commercial brands from the EU market included data on 9 dark air-cured, 31 flue-cured and 57 US blended style products. Figure 7 shows the relationship obtained between acetaldehyde yields and NFDPM yield based on these three blend styles.

These data sets were obtained using similar measurement methods but at different points in time. Even so, the overall correlation between NFDPM and smoke acetaldehyde was high $\left(\mathrm{R}^{2}=0.79\right)$, in spite of the fact that there will be some variability due to temporal measurement differences as well as product differences. $\mathrm{R}^{2}$ correlation values for the individual data sets are given in Table 6 and are similar even though each data set contained a mixture of blend styles.

In this part of the work, the blend sugar content is defined as the sum of sucrose, fructose, and glucose. Brands studied in the 2001, 2005, 2006, 2008, and 2010 data sets were put through the multivariate analysis as previously described.

Acetaldehyde $=\alpha+\beta_{1} \times$ Blend $+\beta_{2} \times$ NFDPM $+\beta_{3} \times$ Sugar

The conclusions from this statistical analysis are given in Table 7. Only NFDPM was significantly related to acetaldehyde yields.

There was no relationship found between the acetaldehyde to NFDPM ratio and blend sugar for these commercial products as depicted in Figure 8.

Some of the most compelling evidence that there is no relationship between blend sugar and acetaldehyde yields generated in cigarette smoke is depicted in Figure 9 for cigarettes made from single tobacco grades. Even though the air-cured tobaccos had less than $0.5 \%$ sugar, when made into cigarettes, they produced acetaldehyde to NFDPM ratios that were similar to those from cigarettes made from the single flue-cured or sun-cured grades containing up to $23 \%$ sugar. 


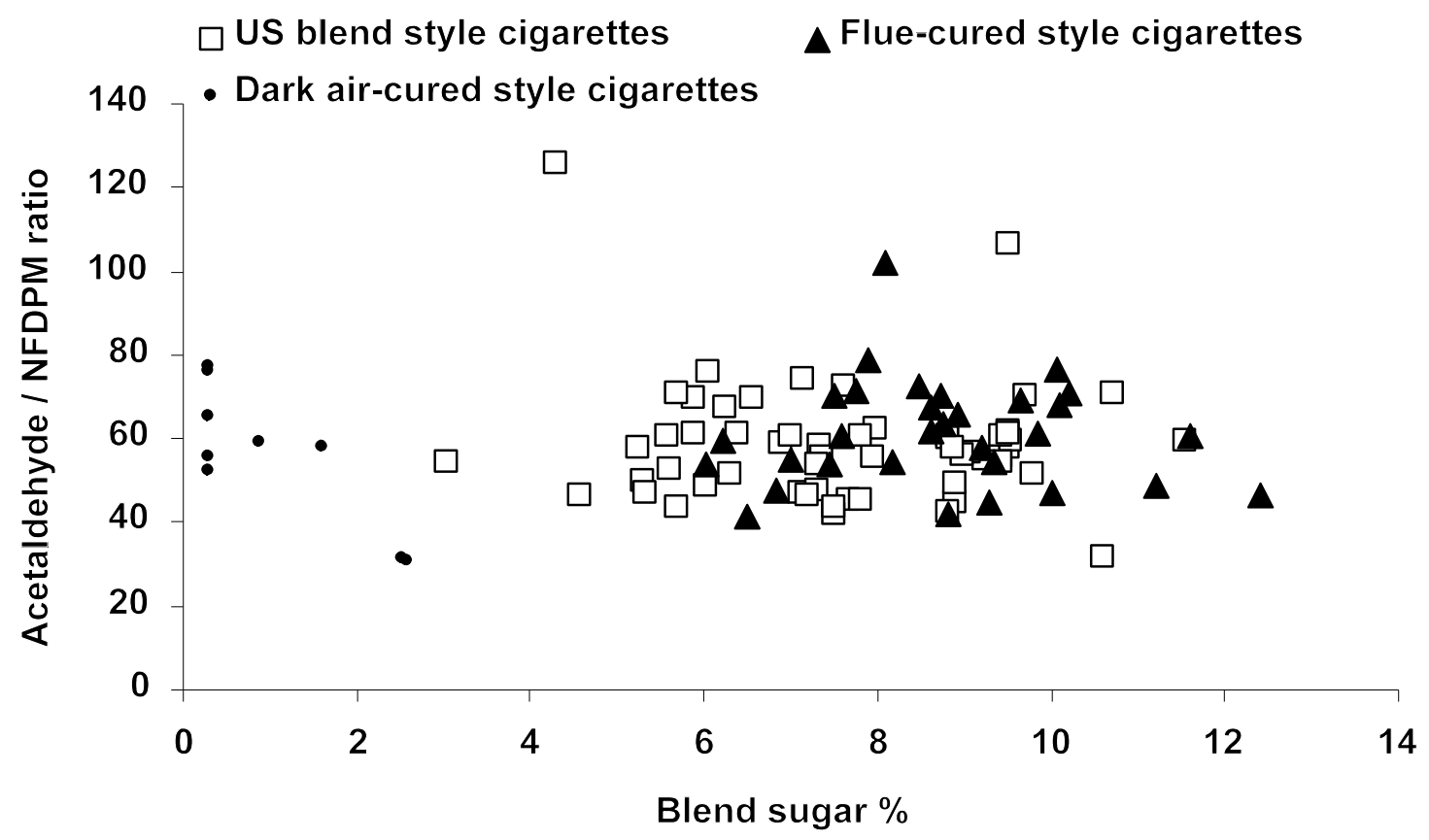

Figure 8. Relationship between the acetaldehyde / NFDPM ratio and blend sugar content for current commercial cigarettes. NFDPM $=$ Nicotine Free Dry Particulate Matter

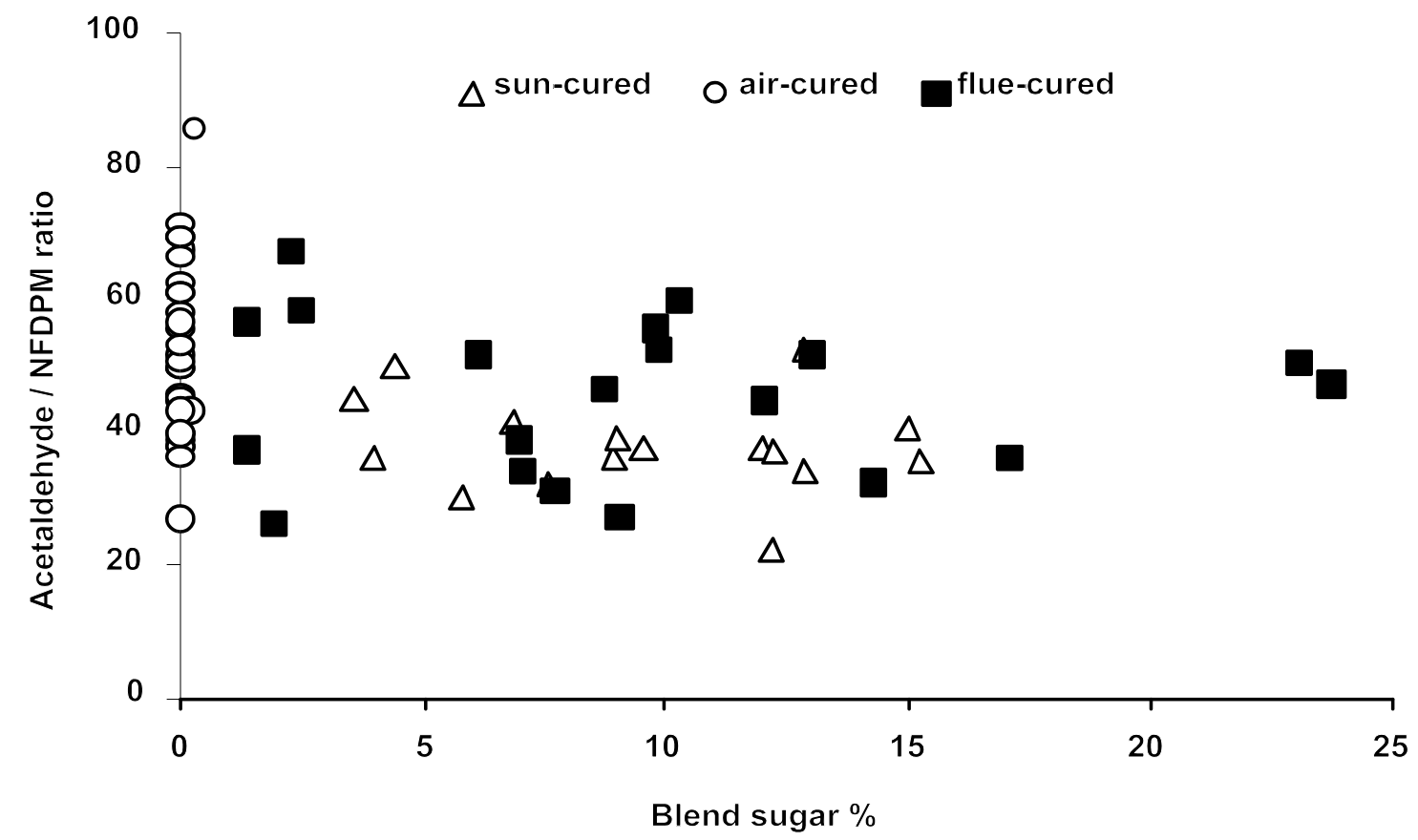

Figure 9. Relationship between the acetaldehyde / NFDPM ratio and blend sugar content for experimental cigarettes made with individual tobacco grades. NFDPM = Nicotine Free Dry Particulate Matter 
Table 6. Correlation of mainstream smoke acetaldehyde with NFDPM yields for the studied data sets of commercial brands.

\begin{tabular}{lcc}
\hline Datasets by year & Number of brands & $\mathrm{R}^{2}$ Correlation \\
\hline Overall & 97 & 0.79 \\
2001 & 25 & 0.84 \\
2005 & 7 & 0.85 \\
2006 & 26 & 0.92 \\
2008 & 17 & 0.79 \\
2010 & 22 & 0.79 \\
\hline
\end{tabular}

NFDPM = Nicotine Free Dry Particulate Matter

\section{CONCLUSIONS}

Using several different data sets and product types, this study has shown that there is no relationship between acetaldehyde yields and blend sugar content even if a multivariate analysis is carried out taking into account NFDPM as a co-factor.

The suggestion (17) to use multivariate analysis instead of the normalisation by dividing by NFDPM yields is very relevant. Nevertheless, it is important to take into consideration each of the factors which can have an impact before drawing conclusions. In the case of the PHILLPOTTS data on 83 European brands, it has been clearly shown that the "country" factor had a large impact on the mainstream smoke acetaldehyde yields and that no relationship between blend sugars and cigarette mainstream acetaldehyde yields has been found even when using multivariate analysis.

No distinction was found between the mainstream acetaldehyde yields from 97 dark air-cured, flue-cured or US blended commercial cigarette types irrespective of their sugar content after taking account of differences in NFDPM yields. Similarly, no distinction was found between mainstream acetaldehyde yields from 65 experimental cigarette types made from either flue-cured, sun-cured or air-cured tobaccos with no sugar added.

This work supports the conclusions that structural material in the tobacco plant is the main source of acetaldehyde in mainstream smoke after combustion during cigarette smoking.

\section{REFERENCES}

1. IARC (International Agency for Research on Cancer): Monographs on the evaluation of the carcinogenic risk of chemicals to humans; World Heath Organization, Lyon, France, 71 (1999).

2. World Heath Organization: Advancing knowledge on regulating tobacco products; WHO, Geneva, Switzerland, 2001.

3. Seeman, J.I., M. Dixon, and H.J. Haussmann: Acetaldehyde in mainstream tobacco smoke: formation and occurrence in smoke and bioavailability in the smoker; Chem. Res. Toxicol. 15 (2002) 1331-1349.

4. Akehurst, B.C.: Tobacco; 2nd Edition, Longman Inc. New York 1981.

5. Talhout, R., A. Opperhuizen, and J.G.C. van Amsterdam: Sugars as tobacco ingredient: effects on mainstream smoke composition; Food Chem. Toxicol. 44 (2006) 1789-1798.

6. Scientific Committee on Emerging and Newly Identified Health Risks (SCENIHR): Addictiveness and attractiveness of tobacco additives; ISBN 978-9279-12788-5. 12th November 2010. Available at: http://ec.europa.eu/health/scientific_committees/emer ging/docs/scenihr_o_031.pdf (accessed November 2011).

7. Hahn, J. and J. Schaub: Influence of tobacco additives on the chemical composition of mainstream smoke; Beitr. Tabakforsch. Int. 24 (2010) 100-116.

8. Sanders, E.B., A.I. Goldsmith, and J.I. Seeman: A model that distinguishes the pyrolysis of D-glucose, D-fructose, and sucrose from that of cellulose. Application to the understanding of cigarette smoke formation; J. Anal. Appl. Pyrolysis 66 (2002) 29-50.

9. Purkis, S.W., C. Mueller, and M. Intorp: The fate of ingredients in and impact on cigarette smoke; Food Chem. Toxicol. 49 (2011) 3238-3248.

10. Carmines E.L.: Evaluation of the potential effects of ingredients added to cigarettes. Part 1: cigarette design, testing approach, and review of results; Food Chem. Toxicol. 40 (2002) 77-91.

11. Rustemeier K., R. Stabbert, H.J. Haussmann, E. Roemer, and E.L. Carmines: Evaluation of the potential effects of ingredients added to cigarettes. Part 2: chemical composition of mainstream smoke; Food Chem. Toxicol. 40 (2002) 93-104.

12. Baker R.R., E.D. Massey, and G. Smith: An overview of the effects of tobacco ingredients on smoke chemistry and toxicity; Food Chem. Toxicol. 42 (2004) Suppl: S53-83.

Table 7. Multivariate analysis of the effects of various factors on acetaldehyde yields using data from commercial cigarettes.

\begin{tabular}{|c|c|c|c|c|c|c|}
\hline Factors & Sum of squares & Degrees of freedom & Mean squares & $\mathrm{F}$ ratio & $P$ value & Significance \\
\hline Blend & 21238.7 & 2 & 10619.3 & 1.42 & 0.2471 & NO \\
\hline NFDPM $^{a}$ & $2.53128 \mathrm{E} 6$ & 1 & $2.53128 \mathrm{E} 6$ & 338.30 & 0.0000 & YES \\
\hline Sugar & 2105.03 & 1 & 2105.03 & 0.28 & 0.5971 & $\mathrm{NO}$ \\
\hline Residue & 688368 & 92 & 7482.26 & & & \\
\hline Total & 3.34789 E6 & 96 & & & & \\
\hline
\end{tabular}

a $\quad$ NFDPM $=$ Nicotine Free Dry Particulate Matter 
13. Intorp, M., J. Pani, and M. Blumenstock: Influence of Tobacco Additives on the Chemical Composition of Mainstream Smoke - Additional Analysis of Three Tobacco Industry Based Laboratories; Beitr. Tabakforsch. Int. 24 (2010) 139-144.

14. Roemer, E., S. Wittke, E. Trelles Sticken, J.J. Piade, T. Bonk, and M.K. Schorp: The addition of cocoa, glycerol, and saccharose to the tobacco of cigarettes: implications for smoke chemistry, in vitro cytotoxicity, mutagenicity and further endpoints; Beitr. Tabakforsch. Int. 24 (2010) 117-138.

15. Gaworski, C.L., K.A. Wagner, M.J. Morton, and M.J. Oldham: Insights from a multi year program designed to test the impact of ingredients on mainstream cigarette smoke toxicity; Inhal. Toxicol. (2011) 1-12.

16. Phillpotts, D.F., D. Spencer, and D.T. Westcott: The effect of natural sugar content of tobacco upon the acetaldehyde concentration found in cigarette smoke; Beitr. Tabakforsch. Int. 8 (1975) 7-10.

17. O'Connor, R.J. and P.J. Hurley: Existing technologies to reduce specific toxicant emissions in cigarette smoke; Tob. Control 18 (2008) 139-148.

18. Tobacco Research Council: Standard methods for the analysis of tobacco smoke; Research Paper 11. 2nd Edition; London UK 1974.

19. ISO Standard 3308: Routine analytical smoking machine - Definition and standard conditions; International Organization for Standardization, Geneva Switzerland 2000.

20. Gregg, E., C. Hill, M. Hollywood, M. Kearney, D. McLaughlin, K. McAdam, S. Purkis, and M. Williams: The UK smoke constituents testing study. Summary of results and comparison with other studies; Beitr. Tabakforsch. Int. 21 (2004) 117-138.

21. Beuter, H. O.: Methods Enzym. Anal.; edited by H.U. Bergmeyer, Publisher: VCH, Weilheim Germany (3rd Edition, Volume 6, 321-327 (1985).

22. Siddiqui, I.R. and N. Rosa: Low molecular weight carbohydrates of tobacco; Tob. Sci. 27 (1982) 130-134.

23. ISO Standard 3402: Tobacco and tobacco products Atmosphere for conditioning and testing; International Organization for Standardization, Geneva Switzerland 1999.

24. ISO Standard 10362: Cigarettes - Determination of water in smoke condensates. Part 1. Gas- chromatographic method; International Organization for Standardization, Geneva Switzerland 1999.

25. ISO Standard 4387: Cigarettes - Determination of total and nicotine free dry particulate matter using a routine analytical smoking machine; International Organization for Standardization, Geneva Switzerland 2000.

26. ISO Standard 10315: Cigarettes - Determination of nicotine in smoke condensates - Gas-chromatographic method. International Organization for Standardization, Geneva Switzerland 2000.

27. Health Canada: Determination of selected carbonyls in mainstream tobacco smoke 1999; Available at: http://www.hcsc.gc.ca/hc-ps/tobac-tabac/legislation/re g/indust/method/_main-principal/carbonyl02-eng.php \#a17 (accessed November 2011).

28. European Commission: On the approximation of the laws, regulations and administrative provisions of the Member States concerning the manufacture, presentation and sale of tobacco products Directive 2001/37/EC of the European Parliament and of the Council; 2001. Available at: http://eur-lex.europa.eu /LexUriServ/LexUriServ.do?uri=OJ:L:2001:194:0026 :0034:EN:pdf (accessed November 2011).

29. Zilkey B.F., W.A. Court, M.R. Binns, E.K. Walker, V.A. Dirks, and P.K. Basrur: Chemical studies on Canadian tobacco and tobacco smoke; Tob. Int. 184 (1982) 83-89.

30. Seeman, J.I., S.W. Laffoon, and A.J. Kassman: Evaluation of relationships between mainstream smoke acetaldehyde and NFDPM and carbon monoxide yields in tobacco blends of U.S. commercial cigarettes; Inhalation Toxicol. 15 (2003) 373-395.

Corresponding author:

Steve Purkis

Imperial Tobacco Limited

PO Box 244, Southville,

Bristol BS99 7UJ, UK

E-mail: steve.purkis@uk.imptob.com 